\title{
破砕性まさ土の低圧条件下におけるせん断特性 \\ SHEAR CHARACTERISTICS OF DECOMPOSED GRANITE SOIL COMPRESSIBLE UNDER LOW PRESSURE
}

\author{
鬼塚克忠*・吉武茂樹** \\ By Katsutada ONITSUKA and Shigeki YOSHITAKE
}

\begin{abstract}
In order to investigate the particle crushing and shear characteristics of decomposed granite soil, consolidation tests and direct shear tests were carried out under unsoaked and soaked conditions. A new type of direct shear box with reduced friction was used to know the shear characteristics under low and moderate pressures. Using the strength parameter obtained from direct shear tests under both pressures, we calculated the safety factors of slopes. The results were summarized as follows : 1) Particle crushing of the soil due to the compression and the shear is considerable. 2) The failure line consists of two straight lines changing the slope at normal stress of $\sigma=20 \mathrm{kN} / \mathrm{m}^{2}$ which correspond to the lower boundary of particle crushing region. 3) The degree of decrease in shear strength due to soaking is greater in the region of low pressures than at moderate pressures. 4) For shallow sliding failures, the safety factors under the low pressures is a little less than that under the moderate pressures.

Keywords: decompased granite soil, direct shear test, low pressure, particle crushing, strength parameter
\end{abstract}

\section{1. まえがき}

土のせん断強度は作用している圧力の大きさで異なる ことは周知のとおりである. 足立・深川ら ${ }^{1)}$ は Fig. 1 に 示すように, 土質工学における圧力範囲と名称の関係を 提案している. ところが, 土のせん断強度については, そのほとんどが従来から, いわゆる通常の圧力範囲 : 49 〜 $294 \mathrm{kN} / \mathrm{m}^{2}\left(0.50 \sim 3.00 \mathrm{kgf} / \mathrm{cm}^{2}\right)$ で議論されること が多かった. その結果として, 明らかにされる土のせん 断特性はその範囲の圧力下のものに限られるのではない かと思われる. しかしながら, 自然斜面や切土・盛土の 人工斜面の表層すべり問題を考える場合には，その土か ぶり圧が非常に小さいことから, 数 $\mathrm{kN} / \mathrm{m}^{2}$ (数 10 $\left.\mathrm{gf} / \mathrm{cm}^{2}\right)$ といったような低圧下での土のせん断特性の把 握が必要であると考えられる. わが国における斜面の崩

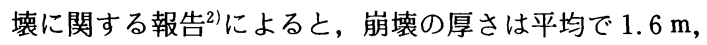
最も多いのが $1.0 \mathrm{~m} \sim 1.5 \mathrm{~m}$ である. このようにわが国 ではすべり面の浅い表層剝離型の斜面崩壊が多い.この 事実からも斜面の安定問題を論ずる場合には, かなり低

* 正会員 工博 佐賀大学教授 理工学部土木工学科 （８40 佐賀市本庄町一）

** 正会員 佐賀大学助手 理工学部土木工学科 (同上)

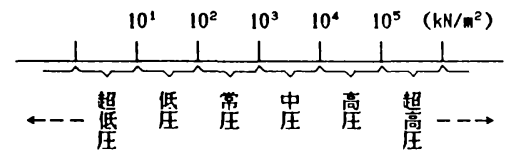

Fig. 1 Range and magnitude of pressures ${ }^{11}$.

い圧力の下での地盤のせん断強度特性の把握が必要であ ることを示している.

最近では低拘束圧下における砂の挙動の研究例 ${ }^{3), 4)}$ は いくらか見受けられる. 龍岡ら ${ }^{4)}$ が Ponce and Bell ${ }^{3)} の$ 試験結果を整理し直したものによると, 拘束圧 $\sigma_{3}^{\prime}$ が $9.8 \mathrm{kN} / \mathrm{m}^{2}\left(0.1 \mathrm{kgf} / \mathrm{cm}^{2}\right)$ 以下では内部摩擦角は $\sigma_{3}^{\prime}$ の 减少に伴って急激な増加を示している. しかし, 龍岡ら ${ }^{5)}$ の豊浦砂についての三軸圧縮試験によると内部摩擦角の 值の拘束圧依存性は $\sigma_{3}^{\prime}$ が $49 \mathrm{kN} / \mathrm{m}^{2}\left(0.5 \mathrm{kgf} / \mathrm{cm}^{2}\right)$ 以 下では $1^{\circ}$ 程度である.このように低拘束圧下の砂の挙 動についてはいくつかの研究報告がある.しかしながら, 実地盤を形成し表層すべりを多発しているまさ土につい て, 低圧下でのせん断特性を扱った研究例 ${ }^{5), 6)}$ はほとん ビない.

まさ土は土粒子が脆弱で破砕しやすい材料であるの で, まさ土の力学的特性に及ぼす粒子破砕の影響は大き 
いと思われる，本論文は，まずはじめに圧密による粒子 破砕の程度を調べ，その試験結果よりまさ土の粒子破砕 特性について考察する．続いて，乱さないまさ土や締め 固めたまさ土および比較のために他の締固め土につい て，改良した一面せん断試験機を用いて低圧域と通常の 圧力域で一面せん断試験を実施し，せん断時における粒 子破砕の影響および両圧力域でのせん断特性の違い，あ るいは関連性について，また水浸の影響について明らか にする.これらの試験結果をもとに両圧力域での斜面安 定解析例を示し，その安全率について検討および考察を するものである.

\section{2. 試料，供試体および試験方法}

\section{（1）試料および供試体}

試験には佐賀市川久保で採取したまさ土を用いた。一 面せん断試験ではまさ土と比較するために砂（豊浦標準 砂）と市販の白色粘土（カオリン）を使用した．おのお のの物性は Table 1 に示すとおりである．まさ土を英文 では Decomposed Granite Soil と表わすが本論文の図, 表では略称として Masa Soil を用いることにする.し たがって, Decomposed Granite Soil と Masa Soil は 同一物と考えてよい，乱さないまさ土は先端にカッター を取り付けた CBR 用モールドを切土斜面に静かに押し 込んで採取した。このモールド内の試料から削り出した ものを乱さない供試体, 所定の密度と含水比をもつよう に調整し静的に締め固めたものを締固め供試体とした。 供試体の大きさはともに直径 $6 \mathrm{~cm}$, 厚さ $2 \mathrm{~cm}$ である.

Table 1 Soil properties.

\begin{tabular}{|c|c|c|c|c|c|c|c|c|c|c|}
\hline \multirow{2}{*}{ Sample } & \multirow{2}{*}{ Gs } & \multirow[b]{2}{*}{$\begin{array}{l}W_{2} \\
(\%)\end{array}$} & \multirow[b]{2}{*}{$\begin{array}{c}y_{p} \\
(\%)\end{array}$} & \multirow{2}{*}{$\begin{array}{l}\text { Yopz } \\
\text { (\%) }\end{array}$} & \multirow[b]{2}{*}{$\begin{array}{l}\rho_{\text {dax }} \\
\left(\mathrm{g} / \mathrm{cm}^{3}\right)\end{array}$} & \multicolumn{4}{|c|}{ Distribution (\%) } & \multirow{2}{*}{$\begin{array}{l}\text { Classi- } \\
\text { fication }\end{array}$} \\
\hline & & & & & & Gravel & Sand & Silt & Clay & \\
\hline Masa Soil & 2.71 & 35 & 25 & - & - & 24 & 66 & 6 & 4 & SM \\
\hline Toyoura Sand & 2.63 & NP & NP & - & - & - & 100 & - & - & $S p$ \\
\hline White Clay & 2.71 & 50 & 25 & 25 & 1.488 & - & - & 40 & 60 & $\mathrm{CH}$ \\
\hline
\end{tabular}

\section{（2）粒子破砕量試験}

粒子破砕量試験には $4.76 \mathrm{~mm}$ 以下の空気乾燥したま さ土を使用した．圧密試験の場合は分取器で分け，自然 含水比になるように調整した試料を自然密度やゆる詰め になるように詰めて供試体を作成した。これを圧密試験 機にセットし，非水浸および水浸条件で段階的に所定の 荷重まで圧密した．圧密時間は乾燥収縮を極力少なくす るよう配慮した結果おのおの 30 分間とした．せん断時 の粒子破砕量を調べる試験では，落下法7)によって初期 状態を調整した試料を分取器で分け, 所定の密度と含水 比になるように静的に締め固めて供試体を作成した。い ずれの試験の場合も，試験終了後ていねいに供試体を取 り出し含水比測定のために炬乾燥した．その後 $74 \mu$ 了

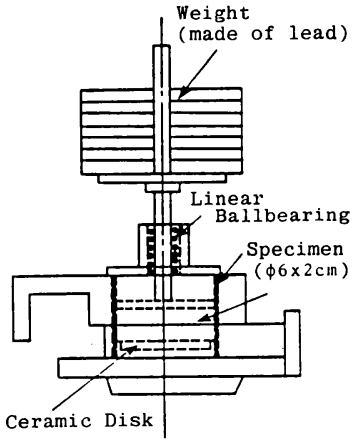

Fig. 2 Shear apparatus (front figure).

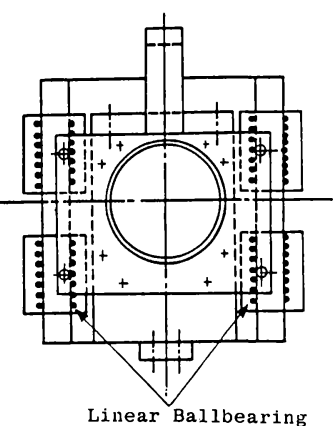

Fig. 3 Shear apparatus (plane figure).
るいで水洗いし炉乾燥後電動式ロータップ型振とう機に よって正味 5 分間のふるい分け試験を行った。なお，供 試体の大きさは両試験とも直径 $6 \mathrm{~cm}$, 厚さ $2 \mathrm{~cm}$ である.

\section{（3） せん断試験}

土のせん断強度を求める試験として一面せん断試験と 三軸圧縮試験がある。一面せん断試験は試料が少なくて すみ供試体が均一である．また，供試体が薄い円柱であ るので乱さない土や締固め土から供試体を削り出すのが 比較的容易である. さらに試験の操作が簡単であり比較 的短時間に数多くのデータを得ることができる，など多 くのメリットがある．一方，欠点としては試験機の機構 上避けることのできない摩擦の問題がある。

そこで摩擦を低減するために新しく製作したせん断箱 を在来型の一面せん断試験機にセットして一面せん断試 験を実施した。低圧によるせん断を行うので，圧密時お よびせん断時の摩擦の影響をできるだけ取り除く必要が ある．新しく製作したせん断箱は供試体と接する内面に はテフロン・ブロンズを張り，載荷装置部分（Fig. 2) とせん断時にスライドする部分（Fig.3）にはボールベ アリングを埋め込み摩擦の低減を行っている．また，改 良型一面せん断試験機と同様にせん断過程に入る前に, 調節ねじで上下せん断箱の間隔を所要の大きさに正しく 保ってせん断するよう工夫してある.

一面せん断試験方法は圧密終了後, ただちにせん断す る非水浸試験（Unsoaked test）と圧密した後，せん断 箱に給水して垂直変位が落ち着いてからせん断する水浸 試験（Soaked test）を乱さない供試体および締め固め た供試体について実施した，不飽和土であるので乾燥収 縮の影響を少なくするように圧密時間は 30 分間程度と

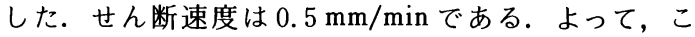
の試験より求まる見掛けの粘着力とせん断抵抗角は排水 条件の $c_{d}, \phi_{d}$ を意味している. 垂直荷重は，低圧域之 して $1.96 \mathrm{kN} / \mathrm{m}^{2} \quad\left(0.02 \mathrm{kgf} / \mathrm{cm}^{2}\right) \sim 17.6 \mathrm{kN} / \mathrm{m}^{2} \quad(0.18$ $\left.\mathrm{kgf} / \mathrm{cm}^{2}\right)$, 通常の圧力域で, $19.6 \mathrm{kN} / \mathrm{m}^{2}\left(0.20 \mathrm{kgf} / \mathrm{cm}^{2}\right)$ 
$\sim 294 \mathrm{kN} / \mathrm{m}^{2}\left(3.00 \mathrm{kgf} / \mathrm{cm}^{2}\right)$ としている.

低圧域と通常の圧力域での側面摩擦を次式 ${ }^{8)} に$ 示す井 上の考えに基づいて調べた.

$\tau=c+\sigma \cdot \tan \phi=c+\tau_{d}+\tau_{r f}+F_{s}$

ここに

$\tau ：$ 測定されたせん断強さ

$c:$ 粘着力

$\tau_{d}$ : ピーク時における体積変化に対する抵抗, $\sigma \cdot(\Delta h / \Delta D)$ に等しい

$\tau_{r f}$ : 粒子間の摩擦抵抗, 残留強度で近似できる

$F_{s}:$ 側面摩擦

今回の試験からは計算上ほとんど摩擦の影響がないと いう結果が得られた。しかしながら, 実際には摩擦が働 いており低圧になるほどその影響も大きいと考えられ る. 一面せん断試験には摩擦等の問題も含んでいるが, 上述したようなメリットを重要視して, 得られた試験結 果をそのまま用いることにした.

\section{3. 粒子破砕特性}

Fig. 4 は乱したまさ土を自然状態の含水比と密度にな るように調整し静的に締め固めたまさ土の $e-\log p$ 曲 線 (非水浸試験) である. この曲線より求められた圧密 降伏応力は $p_{c}=150 \mathrm{kN} / \mathrm{m}^{2}\left(1.53 \mathrm{kgf} / \mathrm{cm}^{2}\right)$ である.こ のまさ土を締め固める前 (採取して空気乾燥後), 圧密 リングに締め固めた後および $1254 \mathrm{kN} / \mathrm{m}^{2} \quad(12.8$ $\left.\mathrm{kgf} / \mathrm{cm}^{2}\right)$ の荷重で圧密後のそれぞれの粒度分布を示し たのが Fig. 5 である．締固めによって生じる粒子破砕は 比較的少ないが，圧密によりかなり粒子破砕が生じるこ とがわかる. 次に, 圧密荷重の増加に伴ってよ゙の程度粒 子破砕量が増えるかを調べるために, Fig. 6 に各ふるい 通過量（\%）の増分（締固め後, 圧密前の粒度曲線を基 準とする）を圧密荷重に対してプロットした.なお，同 図には $e-\log p$ 曲線も併せて示している. 圧密荷重が 大きくなるほど粒子破砕量が増加していることがわか

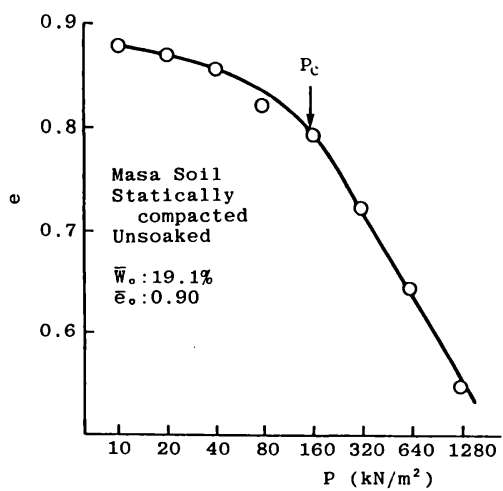

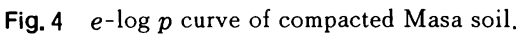

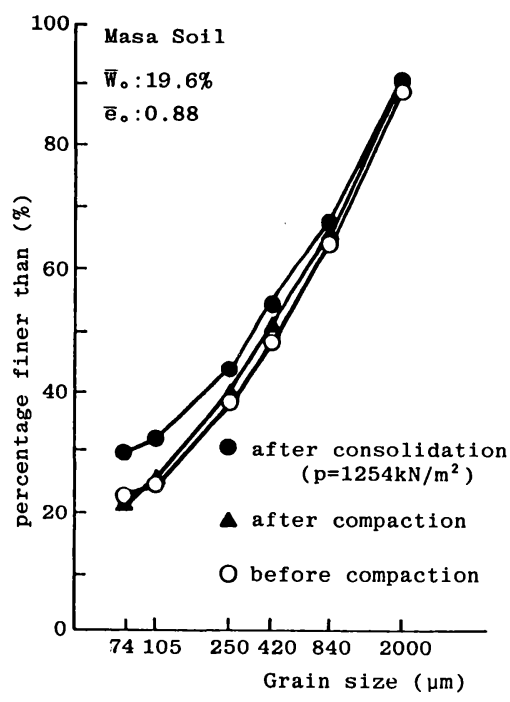

Fig. 5 Effect of compaction and consolidation on particle breakage.

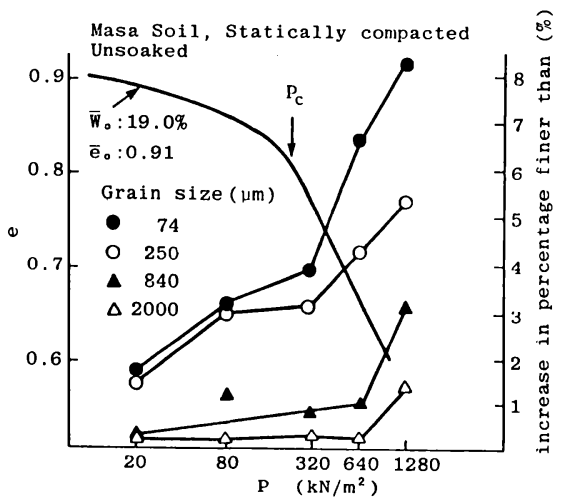

Fig. $6 e-\log p$ curve and increase in percentage finer than each size due to consolidation.

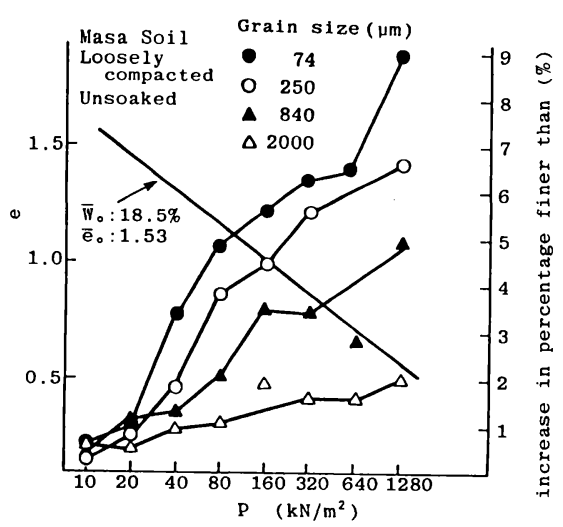

Fig. $7 e-\log p$ curve and increase in percentage finer than each size due to consolidation. 
る. 圧密降伏応力（締固め時の圧力にほぼ等しい）を超 えると粒子破砕曲線の傾きが急増している．圧密降伏応 力を境にして全般的に粒子破砕量は急増するものと予想 したが，大体そのような傾向にあるといえる．そこで， 正規圧密領域における粒子破砕の進行を調べるために， できるかぎり緩く締め固めた供試体についても同様の試 験を実施した. Fig. 7 に示すように, 粒子破砕量は $p=$ $19.6 \mathrm{kN} / \mathrm{m}^{2}\left(0.20 \mathrm{kgf} / \mathrm{cm}^{2}\right)$ 以降ほぼ単調に増加してい ることがわかる.ここで, $p=19.6 \mathrm{kN} / \mathrm{m}^{2}\left(0.20 \mathrm{kgf} / \mathrm{cm}^{2}\right)$ は供試体作成時において負荷された圧縮応力であり, こ の先行応力が粒子破砕曲線に出現したものと考えられ る. 自然状態と同じ初期含水比・密度をもつように締め 固めたものを水浸して圧密試験を行った結果を Fig. 8 に 示す. 粒子破砕量は非水浸試験のもと大差ない. しかし ながら, $e-\log p$ 曲線に明確な圧密降伏応力が現われて いるにもかかわらず粒子破砕曲線はほぼ直線的に増加し ている.これは水浸によりせん断強度が減少したために 土構造が弱化し王密降伏応力以前, つまり過圧密領域に おいても粒子破砕が進行しているためと考えられる.

粒子破砕は 1 つ 1 つ土粒子が圧密圧力や垂直応力の 大きさによって個々に壊れていくのではなく，土粒子間 相互の摩擦によって土粒子の表面部分が削りとられて粒 径が小さくなっていくような形で進行していくものと思

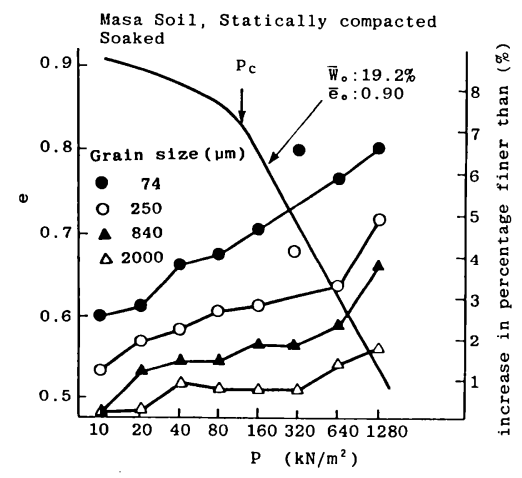

Fig. $8 \quad e-\log p$ curve and increase in percentage finer than each size due to consolidation.

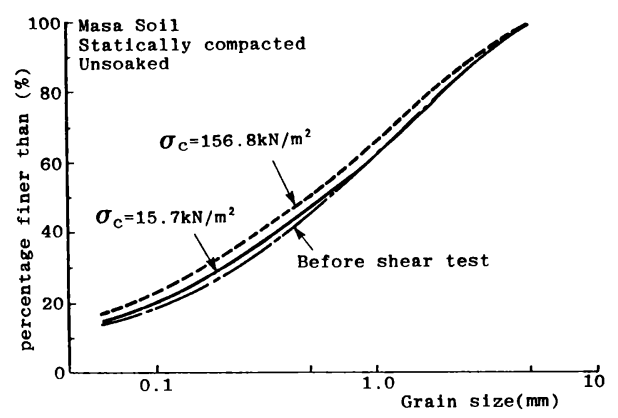

Fig. 9 Grain size accumulation curves after shear test.
われる。

次に，まさ土のせん断時における粒子破砕について考 察する. まさ土粒子は内部構造が複雑なうえ粒径・粒度 の違いによって破砕性にかなりの差があると思われる. そこで, 気乾燥した試料の初期状態を調整し, 静的に締 め固めて供試体を作成し, 非水浸せん断試験を実施した. 低圧および通常の圧力域におけるせん断試験後の粒度分 布を示すとFig.9（破線： $\sigma_{c}=156.8 \mathrm{kN} / \mathrm{m}^{2} \quad(1.60$ $\left.\mathrm{kgf} / \mathrm{cm}^{2}\right)$, 実線 : $\left.\sigma_{c}=15.7 \mathrm{kN} / \mathrm{m}^{2}\left(0.16 \mathrm{kgf} / \mathrm{cm}^{2}\right)\right)$ の ようになる. 垂直応力の大きいものほど粒子破砕が生じ ていることがわかる. Fig. 10には粒子破砕の程度を表 わす量として, 特に $74 \mu \mathrm{m}$ ふるい通過量に着目し, 垂 直応力との関係を示している. 低圧域より通常の圧力域 の方が $74 \mu \mathrm{m}$ ふるい通過量が増加している. Fig. 10 よ りわかるように垂直応力 $\sigma_{c}=19.6 \mathrm{kN} / \mathrm{m}^{2} \quad(0.20$ $\left.\mathrm{kgf} / \mathrm{cm}^{2}\right)$ 付近を境にして垂直応力の増加につれて粒子 破砕の割合が増大しているといえる.

まさ土では垂直応力が $19.6 \mathrm{kN} / \mathrm{m}^{2}\left(0.20 \mathrm{kgf} / \mathrm{cm}^{2}\right)$ 程度でもせん断時に粒子破砕が生じていることが理解で きる.

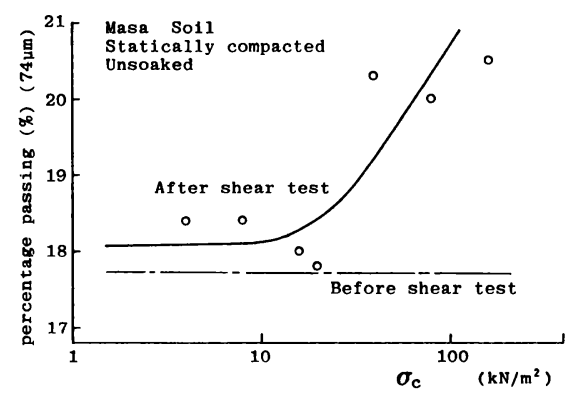

Fig. 10 Percentage passing $(74 \mu \mathrm{m})$ and normal stress.

\section{4. せん断特性}

\section{（1） せん断応力・垂直変位と水平変位の関係}

Fig. 11 には垂直応力が $1.96 \mathrm{kN} / \mathrm{m}^{2}\left(0.02 \mathrm{kgf} / \mathrm{cm}^{2}\right)$ と $196 \mathrm{kN} / \mathrm{m}^{2}\left(2.00 \mathrm{kgf} / \mathrm{cm}^{2}\right)$ の場合（まさ土, 乱さな い供試体, 非水浸) のせん断応力・垂直変位と水平変位 の関係を示している.このまさ土の圧密試験から求めた 圧密降伏応力はおおよそ $p_{c} \fallingdotseq 240 \mathrm{kN} / \mathrm{m}^{2}\left(2.45 \mathrm{kgf} / \mathrm{cm}^{2}\right)$ ありこれをもとに過圧密比を求めると同図の実線は $\mathrm{OCR}=1.2$, 破線は $\mathrm{OCR}=120$ となる. 乱さないまさ 土では, 低圧域および通常の圧力域ともに小さな水平変 位でせん断応力の明確なピークが現われ，その後急激に 減少する，いわゆる脆性的な破壊を示している．乱さな い供試体の場合, 応力-変位曲線は低圧域, 通常の圧力 域ともほぼ同様の傾向を示している，ピークに達してか 


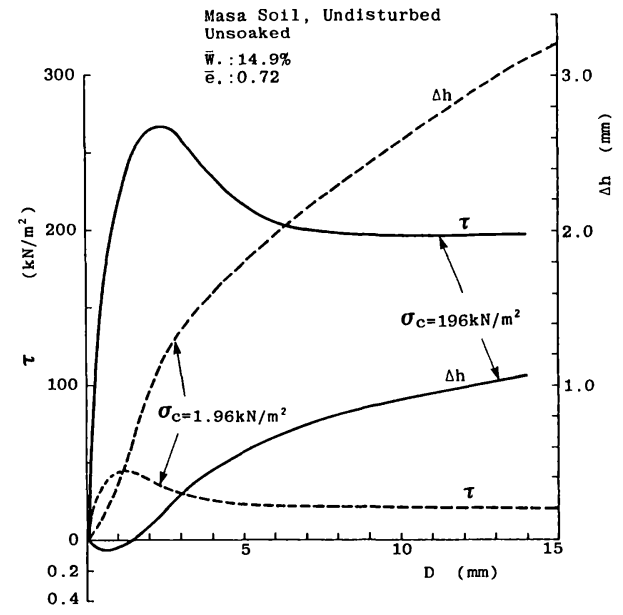

Fig. 11 Effect of magnitude of normal stress on stressdisplacement curve.

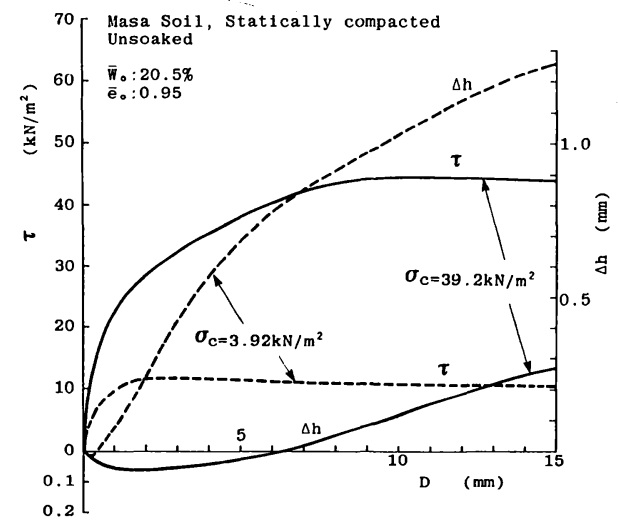

Fig. 12 Effect of magnitude of normal stress on stressdisplacement curve.

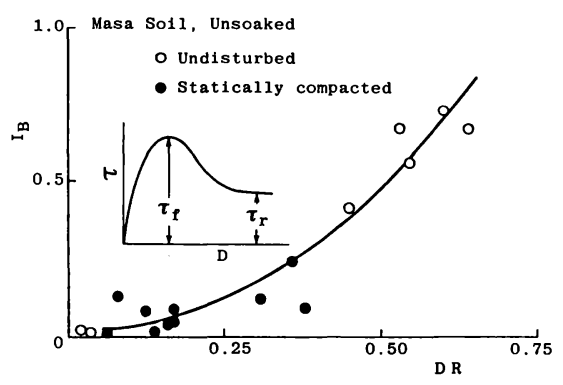

Fig. 13 Brittleness $I_{B}$ and dilatancy rate $D R$.

らのせん断応力の減少の度合は低圧域の方が大きい.

Fig. 12 には垂直応力が $3.92 \mathrm{kN} / \mathrm{m}^{2}\left(0.04 \mathrm{kgf} / \mathrm{cm}^{2}\right)$ と $39.2 \mathrm{kN} / \mathrm{m}^{2}\left(0.40 \mathrm{kgf} / \mathrm{cm}^{2}\right)$ の場合（まさ土, 締固め, 非水浸) のそれを示している. 締め固めたまさ土の場合, 低圧域では, 水平変位の小さなところでピーク強度に達 し, その後はせん断応力の娍少もほとんよ゙なくほぼ一定
の応力状態になる. 一方, 通常の圧力域ではせん断応力 は水平変位の増加に伴い徐々に増大していき, 変位がか なり大きくなるとほぼ一定になる延性的な破壊を示して いる.このように締固め土では, 乱れによる土の固結力 の減少, あるいは締固め時の粒子破砕の影響等により明 確なせん断応力のピークはみられなくなる. 他方, 三軸 圧縮試験では不摫乱供試体と突固め供試体（不摫乱供試 体と同じ初期間隙比をもつ）とを比較すると, ピーク強 度にそれほどの違いはないが，ピーク強度での軸ひずみ あるいは体積変化には大きな差がみられるという報 告 ${ }^{9), 10)}$ がある. 八木ら ${ }^{9)}$ は不䚋乱供試体は突固め供試体 に比べて間隙個々の面積の大きいものが多いので, 三軸 圧縮試験ではより大きな間隙がせん断初期につぶれやす く, したがって, せん断初期に大きな体積王縮を生じ, また応力ーひずみ曲線の立ち上がりも小さいとしている. これらの試験結果と著者らの試験結果とでは, まさ土の 種類, 初期間隙比, 試料の採取方法および供試体の作成 方法等が異なっており単純に比較するのは難しいと思わ れる. 一方, 西田ら ${ }^{11)}$ の乱さないまさ土の一面せん断試 験結果によると, 風化度の違いはあるにせよほぼ本試験 結果と同様な傾向が得られている.

次に垂直変位についてみてみると, 乱さない供試体, 締め固めた供試体ともに低圧域のものほど体積膨張が著 しい. 低圧域の垂直変位は通常の圧力域のものと異なり, せん断応力が一定になっても水平変位の増加とともに漸 増している.その理由については今のところ不明である. 低圧下においては体積膨張性の増大が少なからずせん断 強度に影響を及ぼしている.

Fig. 13 には Bishop ${ }^{12)}$ が提案した脆性指数(Brittleness index $): I_{B}=\left(\tau_{f}-\tau_{r}\right) / \tau_{f}$ (ここで $\tau_{f}:$ ピーク強度, $\tau_{r}$ : 残留強度）と垂直変位-水平変位曲線の傾きのダイレイ タンシーレイト $D R=(\Delta h / \Delta D)_{s}$ の関係を示している. 低圧域のものほどダイレイタンシーレイトが大きく, 脆 性指数も大となる. また乱さない土の方が締固め土より $D R, I_{B}$ ともに大きい.

\section{（2）最大せん断応力と垂直応力の関係}

Fig. 14 はまさ土（締固め, 非水浸), Fig. 15 にはカ才 リン（締固め, 非水浸) と豊浦砂 (締固め, 非水浸) の 垂直応力 $\sigma_{c}$ とピーク強度 $\tau_{f}$ の関係を示している. まさ 土では破壊線の傾きは低圧から圧力域の増大につれて娍 少傾向にある. 一方, カオリンや豊浦砂では圧力域の大 小の違いに関係なく 1 つの直線で両者の関係を表わすこ とができる. Fig. 9 およびFig. 10 に示したように，ま さ土では圧力域の大きいものほどせん断による粒子破砕 量は大きい.このことから, 試料の違いによって破壊線 の形状が異なる原因としては粒子破砕の影響が 1 つの要 因ではないかと考えられる. 三浦ら ${ }^{13)}$ の標準砂について 


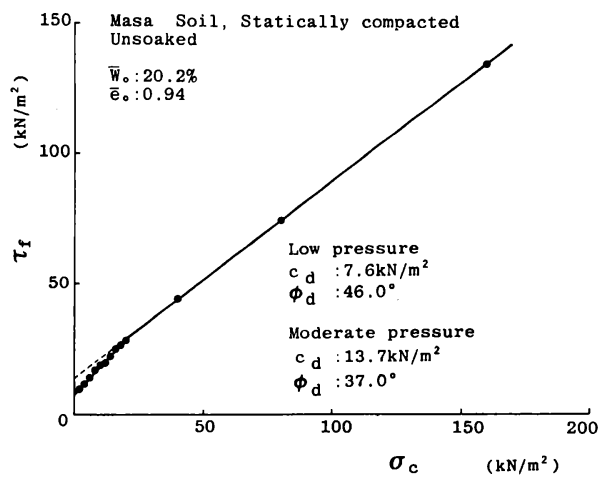

Fig. 14 Failure envelope of Masa soil.

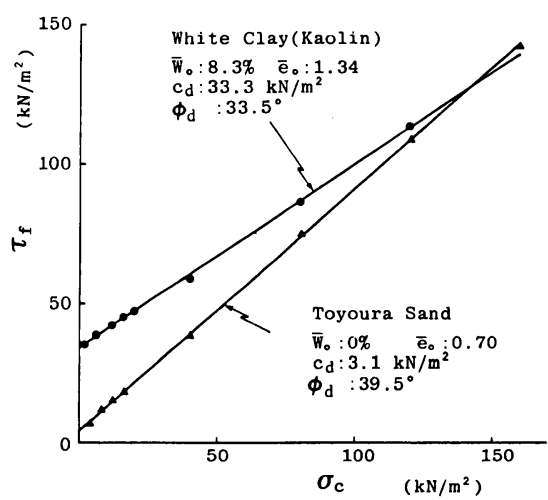

Fig. 15 Failure envelope of White clay and Toyoura sand.

Table 2 Strength parameter under low pressures.

\begin{tabular}{|c|c|c|c|c|c|}
\hline \multicolumn{2}{|l|}{ Sample } & \multicolumn{2}{|c|}{$\begin{array}{l}\text { Cohesion } \\
C_{1}\left(\mathrm{kN} / \mathrm{cm}^{2}\right)\end{array}$} & \multicolumn{2}{|c|}{$\begin{array}{l}\text { Angle of shearing } \\
\text { resistance } \phi_{1}\left(0^{\circ}\right.\end{array}$} \\
\hline & & \begin{tabular}{|l|} 
Unsoaked \\
\end{tabular} & Soaked & Unsoaked & Soaked \\
\hline \multirow{2}{*}{\begin{tabular}{cc|} 
Masa & Soll \\
(Kavakubo)
\end{tabular}} & Und isturbed & 39.2 & 6.4 & 67.0 & 47.5 \\
\hline & Conpacted & 7.6 & 3.6 & 46.0 & 37.5 \\
\hline Toyours Sand & Compacted & 3.1 & - & 39.5 & - \\
\hline White Clay & Coupacted & 33.3 & - & 33.5 & - \\
\hline
\end{tabular}

Table 3 Strength parameter under moderate pressures.

\begin{tabular}{|c|c|c|c|c|c|}
\hline \multicolumn{2}{|l|}{ Sample } & \multicolumn{2}{|c|}{$\begin{array}{l}\text { Colresion } \\
\text { C.e }\left(\mathrm{kN} / \mathrm{cm}^{2}\right)\end{array}$} & \multicolumn{2}{|c|}{$\begin{array}{l}\text { Angle of shearing } \\
\left.\text { resistance } \phi, x^{\circ}\right)\end{array}$} \\
\hline & & Unsoaked & Soaked & Unsoaked & Soaked \\
\hline \multirow{2}{*}{$\begin{array}{l}\text { Masa Soll } \\
\text { (Kabakubo) }\end{array}$} & Indisturbed & 76.6 & 48.0 & 27.5 & 24.5 \\
\hline & Compacted & 13.7 & 4.2 & 37.0 & 34.0 \\
\hline Toyoura Sand & Compacled & 3.1 & - & 39.5 & - \\
\hline White Clay & Compacted & 33.3 & - & 33.5 & - \\
\hline
\end{tabular}

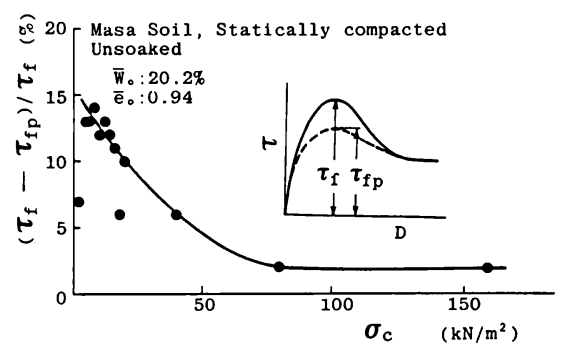

Fig. 16 Effect of dilatancy on shear strength.
の三軸圧縮試験結果によると拘束圧が $2450 \mathrm{kN} / \mathrm{m}^{2}$ $\left(25.00 \mathrm{kgf} / \mathrm{cm}^{2}\right)$ 以下では標準砂のせん断特性に及ぼ す粒子破砕の影響はほとんどないと報告している.今回 実施した試験での垂直応力は最大で $294 \mathrm{kN} / \mathrm{m}^{2} \quad(3.00$ $\left.\mathrm{kgf} / \mathrm{cm}^{2}\right)$ であり，この程度の圧力ではカオリンや砂が 粒子破砕をほとんど起こさないこと, 逆にまさ土は粒子 が破砕しやすい材料 ${ }^{14), 15)}$ であることを考え合わせるとこ の結果は説明がつく.

各試料について強度定数 $c_{d}, \phi_{d}$ を求めてまとめてみ ると Table 2，3のようになる．まさ土の場合には，圧 力域の違いによって強度定数にかなりの違いがみられ, 特に粘着力の差が大きい. 乱さないまさ土では, 試料は 不均質で粗い粒子もかなり含まれる。このため粒子破砕 の影響が少ない低圧域では， $\phi_{\boldsymbol{d}}$ の值はかなり大きくな る.（1）で求べたように低圧条件下におけるせん断で は体積膨張性が著しく，このことが少なからずせん断強 度に影響を及ぼしている。そこで, Taylor の式を用い ダイレイタンシー補正を行い, $\left(\tau_{f}-\tau_{f p}\right) / \tau_{f}\left(\tau_{f}:\right.$ ピー ク強度, $\tau_{f p}$ : Taylor の式を用いたダイレイタンシー補 正後の強度）と垂直応力の関係を示すと Fig. 16 のよ になる.ダイレイタンシーのせん断強度に及ぼす影響は 低圧域の方が通常の圧力域よりも大きいことがわかる. すなわち, 低圧域で 10 数\%, 通常の圧力域で $2 \%$ 程度 ダイレイタンシーによってせん断強度が変化している. しかし, 破壊線の形状はダイレイタンシー補正を行って も変わらない. すなわち, まさ土は破壊線が折れ曲がり, カオリンや豊浦砂では 1 つの直線になる.

強度定数 $c_{d}, \phi_{d}$ に及ぼすダイレイタンシーの影響は せん断抵抗角 $\phi_{d}$ よりも見掛けの粘着力 $c_{d}$ の方が大きい ようである. 低圧および通常の圧力域ともにせん断抵抗 角 $\phi_{d}$ はダイレイタンシー補正を行ってもほとんど変わ らない. しかしながら, 見掛けの粘着力 $c_{\boldsymbol{d}}$ はダイレイ タンシー補正によってかなり減少する. その減少の割合 は低圧域の方が大きく，ほぼ $20 \%$ である.

\section{（）水漫による影聛}

まず, 初めに不飽和土の水浸によるせん断強度低下の 要因について考察すると次のようになる.

土粒子接触点にメニスカスが存在する不飽和土が一軸 方向のもとでっり合っているとすると不飽和土の有効応 力は Bishop によって次式のように示されている.

$$
\sigma^{\prime}=\sigma-u=\sigma-u_{a}+\chi\left(u_{a}-u_{w}\right) \text {. }
$$

ここに, $\sigma^{\prime}$ : 有効垂直応力, $\sigma$ : 全垂直応力, $u$ : 等価 間隙圧, $u_{a}$ : 間隙空気圧, $u_{w}$ : 間隙水圧,

$\chi$ : 飽和度 $S_{r}=100 \%$ で $1, S_{r}=0 \%$ で 0 と なる係数

ここで有効応力の増分 $\chi\left(u_{a}-u_{w}\right)=p$ をサクションに よる粒子間圧縮力, また $u_{a}=0$ のときの $p$ の值, 一 


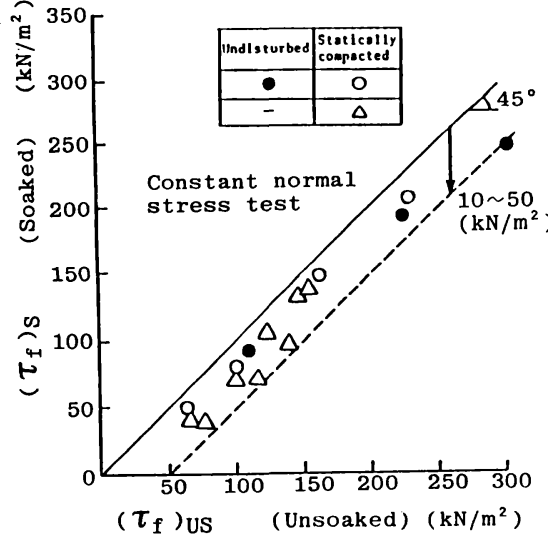

Fig. 17 Shearing strength of soaked and unsoaked specimens.

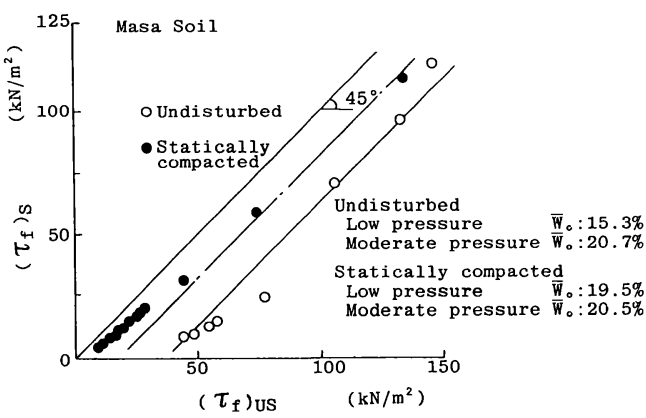

Fig. 18 Shearing strengh of soaked and unsoaked specimens.

$\chi \cdot u_{w}=p^{*}$ を毛管水による粒子間圧縮力と名付ける. 一 般に間隙空気圧は大気圧に通じているので $u_{a}=0$ であ るから

$$
\sigma^{\prime}=\sigma+\chi\left(-u_{w}\right)=\sigma+p^{*}
$$

不飽和状態（非水浸時）のせん断強度は

$$
\tau_{s}=c^{\prime}+\left(\sigma+p^{*}\right) \cdot \tan \phi^{\prime}
$$

となる，いま強度定数 $c^{\prime} ， \phi^{\prime}$ は含水条件に関係なく一 定であると仮定する. 水浸するとメニスカス，すなわち 毛管水による粒子間圧縮力は消失するので, 水浸後のせ ん断強度は

$$
\left(\tau_{f}\right)_{s}=c^{\prime}+\sigma \cdot \tan \phi^{\prime}
$$

となる.この值は非水浸時のせん断強度（式 $(3))$ に 比べて少なくとも $p^{*} \cdot \tan \phi^{\prime}$ だけは小さくなっている. これが不飽和土の水浸によるせん断強度の低下であり， 垂直応力 $\sigma$ には無関係である. まさ土について水浸に よる影響を示すと Fig. 17 16),17)，Fig.18のようになる. 水浸すると非水浸に比べて強度はかなり減少する. しか し, その低下の度合いは圧密, せん断時の垂直応力には ほぼ無関係である。

水浸によるせん断強度の低下率は次式で表わせる.

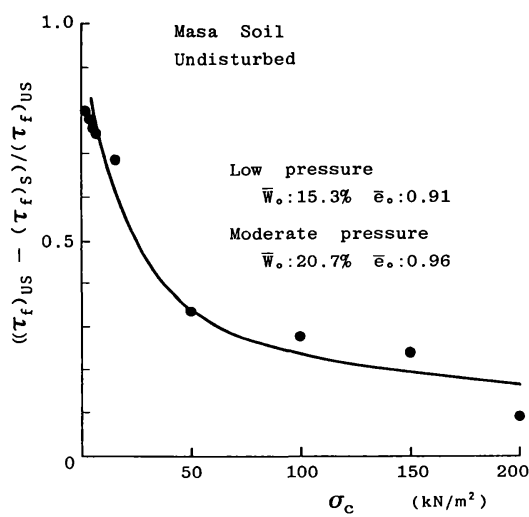

Fig. 19 Effect of normal stress on ratio of strength decrease.

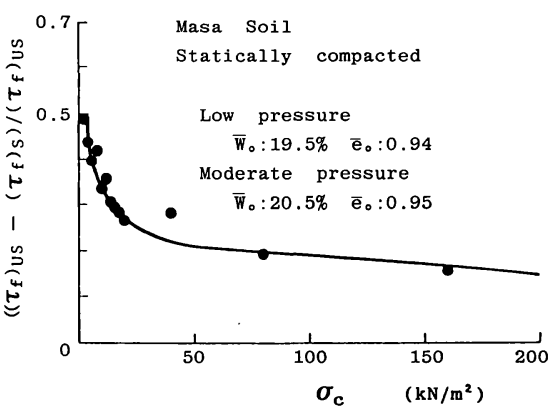

Fig. 20 Effect of normal stress on ratio of strength decrease.

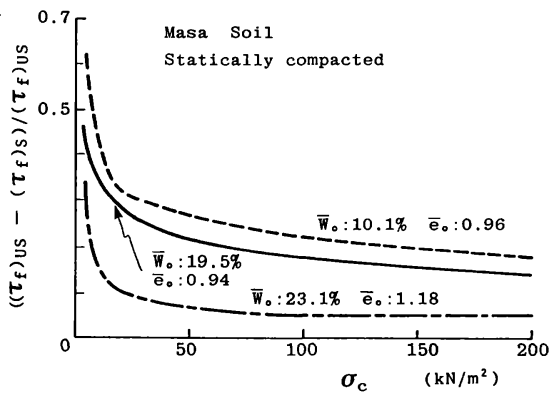

Fig. 21 Effect of initial water content and normal stress on ratio of strength decrease.

$$
\frac{\left(\tau_{f}\right)_{U s}-\left(\tau_{f}\right)_{s}}{\left(\tau_{f}\right)_{U S}}=\frac{\tau_{f}-\left(\tau_{f}\right)_{s}}{\tau_{f}}=\frac{p^{*} \cdot \tan \phi^{\prime}}{c^{\prime}+\left(\sigma+p^{*}\right) \cdot \tan \phi^{\prime}}
$$

Fig. 18 に示したまさ土の水浸による強度低下率と垂 直応力との関係は Fig. 19 (乱さないまさ土), Fig. 20 (締 め固めたまさ土）のようになる. 通常の圧力域では低下 率はほぼ一定であるが, 低圧になるにつれて大きくなっ ており，垂直応力が $19.6 \mathrm{kN} / \mathrm{m}^{2}\left(0.20 \mathrm{kgf} / \mathrm{cm}^{2}\right)$ 以下 になると水浸による強度低下率は急激である，また，初 期含水比の異なる締め固めたまさ土について水浸による 強度低下率の違いを調べたのが Fig. 21 である. 初期含 
水比の小さいものほど低下が大きく, 低圧域になるほど 急激である。

低圧域の方が水浸による強度低下率が大きい理由につ いては式（5）で説明できる.すすわち， $p^{*} \cdot \tan \phi^{\prime}$ は Fig. 17, Fig.18に示したように垂直応力の大きさ（ $\sigma$ の大小）に無関係にほぼ一定であり, 式（5）の值は垂 直応力 $\sigma$ が小さいほざ大きくなる. 垂直応力 $\sigma$ の值が 小さいほよ゙, $\left(\left(\tau_{f}\right)_{U S}-\left(\tau_{f}\right)_{s}\right) /\left(\tau_{f}\right)_{U S}$ の値は大きい.よって, 低圧になるほぼせん断強度の低下率は大きい。

次に, 強度定数 $c_{d}, \phi_{d}$ に及ぼす水浸の影響について みてみると，Table 2, 3 に示す水浸後のこれらの值は 非水浸に比べてかなり小さくなっている. 一般に，水浸 による $c_{d}, \phi_{d}$ の低下率は低圧域のものほよ゙大きいよう である．それゆえ，表層剥離型の崩壊を多発しているま さ土 ${ }^{18)}$ 実地盤における地表面下 $1 \sim 2(\mathrm{~m})$ 付近の表層部 分では, 雨水等による浸水の影響がかなり大きいと考え られる.

\section{5. 強度定数 $c_{d}, \phi_{d}$ の变化を考慮した斜面の 安定計算}

土の強度定数 $c_{d}, \phi_{d}$ はせん断過程において一定值で はなく水平変位（ひずみ）の増加に伴って変化する．す なわち水平変位の増加に伴って発現される強度定数 $c_{d}$, $\phi_{d}$ は垂直応力と各水平変位ごとのせん断応力の直線近 似によって決定できる．よって水平変位をパラメーター として土の強度定数 $c_{d}, \phi_{d}$ の発現過程を表わすことが できる ${ }^{19,201}$.

実際の盛土や切土斜面内の応力とひずみの分布は一様 ではないので, これらの安定問題を考察する場合（進行 性破壊を考慮）にはひずみの大きさに応じた強度定数を 用いる方が望ましいのではないかと考えられる．すなわ ち，斜面内において応力が集中し，大きなひずみを生じ ている部分には残留状態から得られた強度定数を用いる べきではないかと思われる．しかしながら，本報告は低 圧および通常の圧力域における強度特性の違い，あるい は関連性を主目的としているのでこの点についての検討 は別の機会に譲りたい，本論文では便宜上すべり面上の 各点が一様に変位すると仮定し，この変位に応じた強度 定数 $c_{d}, \phi_{d}$ を用いて安全率を算出し，低圧域および通 常の圧力域で得られた強度定数を用いた場合の安全率の 変化を考察した。

Fig. 22 は斜面勾配を一定とし，すべり層厚の違いに よる安全率の変化を水平変位に対してプロットしたもの である．なお，同図にはピーク強度の $c_{d}, \phi_{d}$ より求め た安全率を一点鎖線で付記している，乱さないまさ土の 場合，すべり層厚が浅くなるほど安全率は明確なピーク を示し，せん断変位が大きくなればかなり小さくなる.

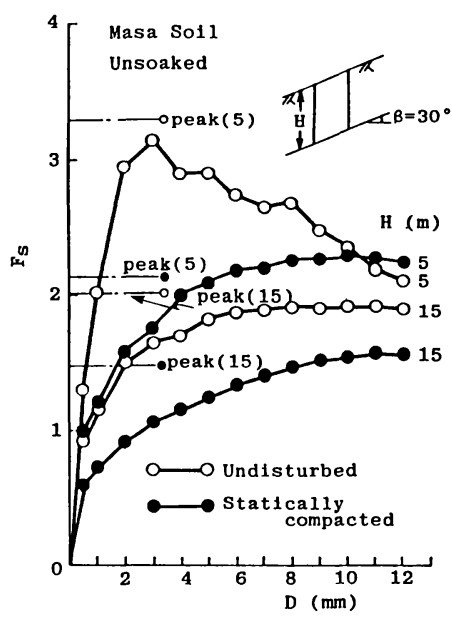

Fig. 22 Variation of safety factor of infinite slope with shear displacement.

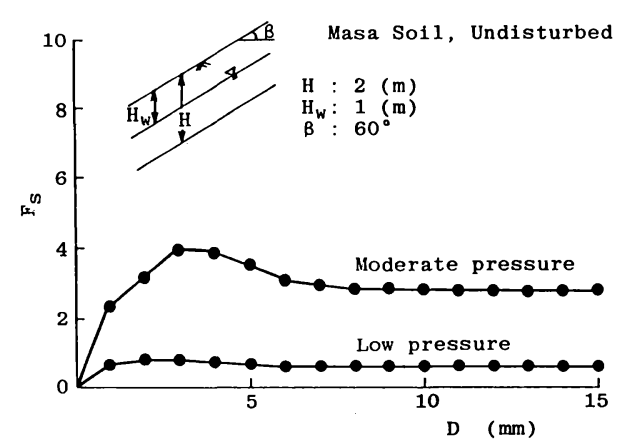

Fig. 23 Effect of horizontal displacement $D$ and magnitude of pressure on safety factor $F_{s}$.

このようにすべり層厚が浅い場合は進行性破壊が生じる ことを意味しており, 残留状態における安全率をも考慮 する必要があると思われる．静的に締め固めたまさ土で は安全率はせん断変位とともに漸増する，以上のことは 有限斜面（円弧すべり）の場合も同様である。

Fig. 23 は斜面を無限長斜面, すべり面の深さ $(H)$ は地表面下 $2.0(\mathrm{~m})$, その傾き $(\beta)$ は 60 度, 地表面か ら深さ $H_{w}=1.0(\mathrm{~m})$ に地表面と平行な浸潤面をもつ定 常浸透流が存在すると仮定し，Fig. 19 に示した乱さな いまさ土の試験結果の值を用いて計算した安全率と水平 変位の関係を示している. 図より明らかなように, 低圧 下で得られた値を用いた安全率の方が通常の圧力域のも のを用いた場合よりもかなり小さくなっており，安全率 が 1.0 を下回っている. Fig. 23 のような斜面を考えた 場合には，土かぶり圧に応じた圧力範囲，すなわち低圧 域で得られた強度定数 $c_{d}, \phi_{d}$ を用いないと安全率を過 大に見積もる可能性があることを示している. 4. (2) で述べたように低圧域と通常の圧力域では強度定数, 特 
に粘着力に違いが出てくる. 浅層すべりの安定問題では 低圧下における見掛けの粘着力の影響がきわめて大き い.

斜面の安定解析を行う場合には，せん断変位の増加に 伴う強度定数の変化, すべり層の厚さ, 斜面勾配等が複 雑に関係しており問題点も多い。しかしながら，すべり 層厚が小さく勾配が急な斜面を考えた場合には，低圧下 で得られる強度定数を用いた安全率は小さい.ゆえに, 低圧下における土の強度定数を用いた安定計算の方がよ り合理的と考えられる.

\section{6. ま と め}

乱さないまさ土および締め固めたまさ土について圧密 試験, 一面せん断試験を行い粒子破砕特性および低圧域 之通常の圧力域でのせん断特性の違いや関連性, また, 両圧力域でのせん断特性に及ぼす水浸の影響を明らかに した。さらにせん断試験より得られた結果を用いて斜面 の安定解析を行い, 低圧域および通常の圧力域における 斜面の安全率について考察した.

（1）圧密による粒子破砕はかなり大きい. 圧密降伏 応力（締固め時の圧力にほぼ等しい）を超えると粒子破 砕量は増加する. 特に $250 \mu \mathrm{m}$ 以下の粒子の増加が著し い. 粒子破研特性に及ぼす水浸の影響は現段階では明確 ではない。

（2）せん断時の粒子破砕量は垂直応力 $\sigma_{c}$ が 19.6 $\mathrm{kN} / \mathrm{m}^{2}\left(0.20 \mathrm{kgf} / \mathrm{cm}^{2}\right)$ より大きくなると増大する.す なわち通常の圧力域の方が低圧域よりも粒子破砕量は大 きい。この粒子破砕量の違いがせん断強度特性に影響を 及ぼしているものと思われる.

(3) 垂直応力 $\sigma_{c}$ とピーク強度 $\tau_{f}$ の関係から得られ る破壊線は, まさ土の場合, $\sigma_{c}=19.6 \mathrm{kN} / \mathrm{m}^{2}(0.20$ $\left.\mathrm{kgf} / \mathrm{cm}^{2}\right)$ 付近で折れ曲がる. すなわち, 破壊線の傾き は低圧から通常の圧力域へと圧力の増大につれて诚少傾 向にある．一方，カオリンや砂では低圧および通常の圧 力域に関係なく 1 つの直線になる.

（4）まさ土のような粒子破砕性に富む材料では，低 圧および通常の圧力域とでは強度定数 $c_{d}, \phi_{d}$ の值が異 なる．低圧域では $\phi_{d}$ が大きく, $c_{d}$ が小さい. 特に, 粘 着力 $c_{d}$ の差が大きい.

（5）水浸による強度低下率は低圧になるほど大きく 急激である. また, 初期含水比の違いによっても強度低 下率が異なる. すなわち, 初期含水比の小さいものほど 低下率は大きい.

（6）乱さないまさ土ではすべり層厚が小さくなると 安全率は明確なピークを示し, せん断変位が増すと安全 率は小さくなる。浅層すべりの場合, 進行性破壊が生じ ることを意味している.
（7）すべり層厚が小さく勾配が急な斜面の場合に は, 低圧域から得られた強度定数 $c_{d}, \phi_{d}$ を用いて安定 計算を行う方が安全率は小さくなり，より合理的である.

（8）以上のことから, 自然斜面，切土斜面や盛土の 表層すべりの安定問題を取り扱う場合には，水浸による 強度低下を考慮した低圧条件下における強度特性の把握 亡考察が必要である.

謝辞：中野和久君（昭和 61 年 3 月卒業）ならび に島田文章君（昭和 62 年 3 月卒業）にはまさ土の粒子 破砕特性とせん断特性の試験を担当していただきまし た。ここに深く謝意を表します。

\section{参 考 文 献}

1）足立紀尚・深川良一：高圧, 低圧下における土の挙動, 土と基礎, Vol. 32, No. 2, pp. 5 9, 1984.

2）奥園誠之，ほか 3 名：土砂災害の予知亡対策，4, 崩壊 (そ の 1)，土と基礎，Vol.31，No.11，pp. 89 96，1983.

3) Ponce, V. M. and Bell, J. M. : Shear strength of sand at extremely low pressures, Journal of the SMFE, ASCE, SM 4, pp. 625 638, 1971.

4）龍岡文夫・福島伸二・生原 修: 低圧下における三軸圧 縮試験之模型支持力試験, 土と基礎，Vol. 32，No.2, pp. $57 \sim 64,1984$.

5）吉武茂樹・鬼塚克忠：超低圧下における土のせん断特性, 昭和 60 年度土木学会西部支部研究発表会講演概要集, pp. $364 \sim 365,1986$.

6）吉武茂樹・鬼塚克忠：低圧下における不飽和土のせん断 特性, 第 21 回土質工学研究発表会, pp. 277 278, 1986.

7）土質試験法：第 7 編 特殊土の試験，第 3 章 まさ土, p. 7-3-12, 1984.

8）井上広胤：砂の直接せん断に関する研究, 土木学会論文 報告集, No.101, pp. 15 24, 1964.

9）八木則男・矢田部龍一：不摜乱まさ土のせん断特性と微 視的考察, 土木学会論文報告集, No. 364, pp. 133 141, 1985.

10）村田秀一・安福規之・浦口泰弘：乱さないまさ土供試体 のせん断強度特性, 第 19 回土質工学研究発表会講演集, pp. 497 498, 1984.

11）西田一彦・青山千彰・中山義久：乱さない不飽和まさ土 のせん断強度特性, 第 16 回土質工学研究発表会講演集, pp. 533 536, 1981 .

12) Bishop, A.W. et al. : A new ring apparatus and its application to the measurement of residual strength, Géotechnique, Vol.21, No.4, pp.273 328, 1971.

13）三浦哲彦・山内豊聡：高拘束圧における標準砂の排水せ ん断特性について, 土木学会論文報告集, No. 193, pp. 69 79, 1971.

14）松尾新一郎・福本武明：マサ土の破砕性に影響する諸要 因, 土質工学会論文報告集, Vol. 16, No. 4, pp. 87 92, 1976.

15）松尾新一郎・福本武明：マサ土の風化と破研性の関係, 土質工学会論文報告集, Vol. 17, No. 4, pp. 99 106, 1977. 
16）鬼塚克忠・吉武茂樹：佐賀県のまさ土の工学的特性, 低 平地防災技術研究会報告, No. 3, 佐賀大学理工学部土木 建設工学科, pp. 55 78, 1986.

17) Onitsuka, K. and Yoshitake, S. : Influence of initial water content and soaking on compressibility and shear strength of decomposed granite soil, Symposium on environmental geotechnics and problematic soils and rocks, AIT, Bangkok, pp. 911 930, 1985.

18）網干寿夫：自然斜面および切土の安定性, 風化花崗岩と
まさ土の工学的性質とその応用, 土質基礎工学ライブラ リー, 16, pp. 273 275, 1979.

19）鬼塚克忠・吉武茂樹：せん断ひずみの進行に伴う強度定 数の変化, 佐賀大学理工学部集報, No. 13, pp. 23 29, 1985.

20）鬼塚克忠・吉武茂樹：せん断変形に伴う強度定数 $c, \phi$ の変化に関する考察, 土木学会論文報告集, No. 382, III -7 , pp. 265 268, 1987.

(1988.1.11 • 受付) 